\title{
Parotid Gland Mucosa-Associated Lymphoid Tissue Lymphoma
}

National Cancer Institute

\section{Source}

National Cancer Institute. Parotid Gland Mucosa-Associated Lymphoid Tissue

Lymphoma. NCl Thesaurus. Code C35687.

\begin{abstract}
A low-grade extranodal marginal zone lymphoma of mucosa-associated lymphoid tissue arising from the parotid gland. It is the most common type of non-Hodgkin lymphoma in the parotid gland and is often associated with Sjogren syndrome. The prognosis is favorable.
\end{abstract}

